\title{
Diagnosis and management of trigeminal
} neuropathic pains

Joel J Napeñas ${ }^{\dagger 1} \&$ Joanna M Zakrzewska²
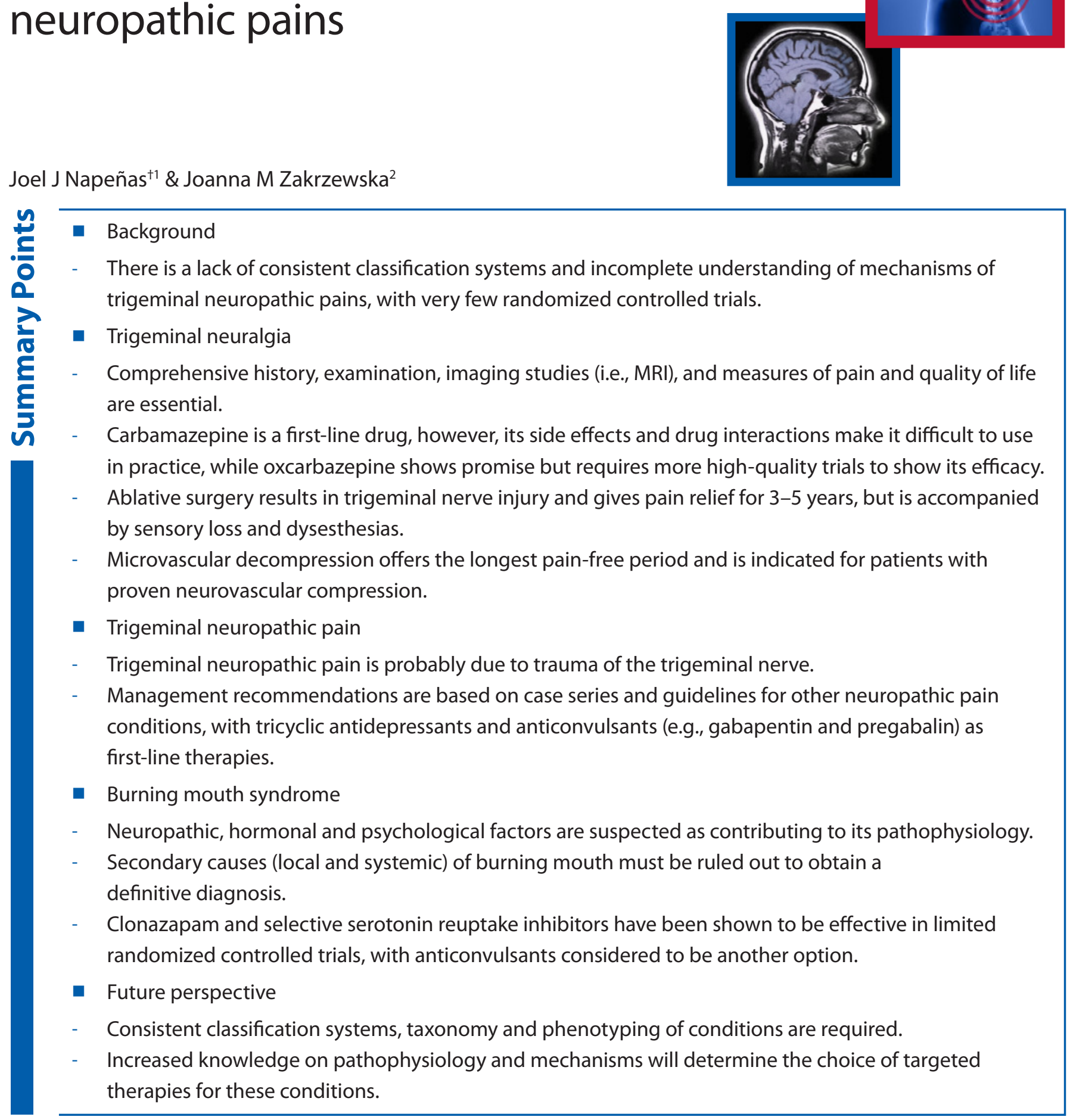
SUMMARY Trigeminal neuropathic pains have presented diagnostic and therapeutic challenges to providers. In addition, knowledge of pathophysiology, current classification systems, taxonomy and phenotyping of these conditions are incomplete. While trigeminal neuralgia is the most identifiable and studied, other conditions are being recognized and require distinct management approaches. Furthermore, other facial pain conditions such as atypical odontalgia and burning mouth syndrome are now considered to have neuropathic elements in their etiology. This article reviews current knowledge on the pathophysiology, diagnosis and management of neuropathic pain conditions involving the trigeminal nerve, to include: trigeminal neuralgia, trigeminal neuropathic pain (with traumatically induced neuralgia and atypical odontalgia) and burning mouth syndrome. Treatment modalities are reviewed based on current and best available evidence. Trigeminal neuralgia is managed with anticonvulsant drugs as the first line, with surgical options providing variable results. Trigeminal neuropathic pain is managed medically based on the guidelines for other neuropathic pain conditions. Burning mouth syndrome is also treated with a number of neuropathic medications, both topical and systemic. In all these conditions, patients need to be thoroughly educated about their condition, involved in its management, and be provided with supportive and adjunctive treatment resources.

Neuropathic pain has been recently redefined by an international group of experts as pain arising as a direct consequence of a lesion or disease affecting the somatosensory system [1]. There are no universally accepted classification systems specifically for facial neuropathic pains. In recent years, studies examining the specific pathophysiology of the various trigeminal neuropathies or altered neuronal function has emerged [2]. With the lack of consistent classification system and slowly emerging understanding of mechanisms, the management of individual conditions continues to be a challenge [3]. There is a lack of data on the incidence and prevalence of neuropathic facial pains, however, the prevalence of all neuropathic pains has been reported to be in the range of 2 to $11 \%[4-6]$. As a result of neuropathic pains and their treatment side effects, patient impairment in quality of life, productivity and excess utilization of healthcare resources are common $[7,8]$.

In the International Classification of Headache Disorders (ICHD-II) cranial neuralgias and central causes of facial pain, the following trigeminal neuropathic pains are listed trigeminal neuralgia (TN), postherpetic neuralgia and nasociliary and supra-orbital neuralgia [9]. There is also a section listed as "other cranial neuralgias and other centrally mediated facial pain". This classification now needs to be updated [10] in view of emerging new data [11], which has led to the formation of two international taskforce committees comprising of multidisciplinary teams. It has been suggested that terms such as trigeminal neuropathic pain, painful traumatic trigeminal neuropathy traumatically induced neuralgias (TIN) and atypical odontalgia (AO) are being used which have many similar features and may all represent forms of neuropathic pain [12]. Recently a group of experts under the guidance of ontologists have suggested that a more accurate term for those within the oral cavity is continuous chronic dentoalveolar pain, subdividing those with a known cause from others with no known primary cause, with further subdivision into those with or without sensory change [13]. There would remain a category of neuropathic facial pain which would follow the same principles as previously suggested [14]. There is also increasing evidence that burning mouth syndrome (BMS) is a continuous neuropathic pain [15]. Covered elsewhere is a distinct category of conditions termed the trigeminal autonomic cephalgias, which are neuralgiform and primarily affect the first division of the trigeminal nerve [16].

\section{Trigeminal neuralgia}

Trigeminal neuralgia is an excruciating, unilateral, severe and short-lasting $(<2 \mathrm{~min})$ pain that may be spontaneous or triggered by gentle, innocuous stimuli. Current classification defines 'classical' TN (CTN) (previously idiopathic or primary) that may or may not be related to neurovascular compression, and comprises the majority of cases $(>85 \%)$ of TN. Secondary TN (STN) (previously symptomatic) is the rarer form that is attributed to previous trauma, pathology (e.g., benign and malignant tumors, 
cysts, demyelination, A-V malformations) or secondary systemic disease [17]. Not recognized by the current classification system are 'atypical' TN (ATN) or type 2 cases, in which there are classical features of TN, but also a background burning, dull type of pain. Such cases are more refractory to treatment. It remains to be seen whether these are the same condition, or arise from different pathophysiologies. TN has been reported to be a rare disorder with reported incidences in the range of $4.5 / 100,000$, slight predilection towards females, and occurrence in the 50-70-year-old age group [18-20]. However, more recent studies suggest high incidences ranging from 28 to $12 / 100,000$, but also highlight the high level of misdiagnosis, as TN has been frequently confused with dental pathology leading to unnecessary dental treatment $[19,20]$. These new data suggest that TN may be more common and occur in younger age groups. Differential diagnosis of TN includes dental pain, sinusitis, short-lasting unilateral neuralgiform headaches with conjunctival injection and tearing (SUNCT), its variant SUNA where any autonomic features can occur, and atypical (shorter) cluster-tic syndrome [16].

The etiology and pathophysiology of TN has remained difficult to determine, although it is hypothesized that compression of the trigeminal root at or near the dorsal root entry zone by a blood vessel is a causative or contributive factor. Surgical data have consistently failed to provide high quality data linking phentotype, MRI findings, operative findings and long-term outcome, therefore it is not possible to provide conclusive evidence that TN is caused solely by compression of the trigeminal nerve. A recent study using ultra-high-filed MRI found high incidences of neurovascular compression in individuals $(92 \%)$ with no symptoms of TN and so suggests that there are other mechanisms involved [21]. Another suggestion exists that arachnoid thickening around the trigeminal nerve root can cause angulation, torsion or stretching of the nerve [22]. The most widely accepted theory is the 'ignition hypothesis', in which pathologic changes or injuries make the axons and somata hyperexcitable, resulting in synchronized afterdischarge activity that gives rise to paroxysmal pain [23], however, with the absence of data in human subjects this theory has been questioned and challenged. It has been suggested that these peripheral abnormalities may result in hyperexcitability of nociceptive neurons in the trigeminal nucleus and/or other central brain areas $[24,25]$. A recent study using functional MRI in a highly selected group of CTN patients, some of whom underwent Gasserian ganglion surgery, showed that ipsilateral sensitization of the trigerminal nucleus $(\mathrm{SpV})$ was no longer present after successful surgery [26]. They suggest that $\mathrm{SpV}$ activation may be specifically linked to evoked pain and may represent hyperexcitabilty of nociceptive trigeminal neurons. However, in those with spontaneous pain or lack of evoked pain who still show changes in the somatosensory system, psychological factors may be playing a role in the maintenance of pain. This would lend support to a small study which showed that central changes with overactivation of central facilitation of trigeminal nociceptive processing occured more frequently in individuals with ATN than CTN [27-29].

The distinguishing features of CTN are the timing of the attacks and the remission periods, with spontaneous or evoked attacks of several seconds along the distribution of a nerve branch, followed by pain-free periods [30]. Those with ATN report longer attacks with a constant, burning, dull background pain [31]. In 97\% of cases, pain is unilateral, mostly involving the second or third branch of the trigeminal nerve [32]. In the event that the patient reports bilateral pain, further investigation is warranted to distinguish from STN. Quality of life is impaired, with inability to socialize and eat leading to weight loss and marked changes noted on measures such as the Brief Pain Inventory and EuroQol (EQ-5D) [33]. Depression and anxiety is commonly reported, with suicidal ideation in extreme cases [34,35]. Patients with CTN report no sensory deficits, however, quantitative sensory testing will distinguish it from STN or other entities, as it has been reported that $15-20 \%$ of patients also exhibit sensory loss in the affected branch [36]. The condition has no autonomic features. MRI is useful to rule out STN, and is used to identify and locate nerve compression, however, studies have shown that neurovascular compression occurs frequently in asymptomatic individuals [21].

Long-term follow-up has shown TN to have a course of well-defined periods of pain attacks followed by periods of remission. Additionally, the prognosis is poor, with approximately $90 \%$ of patients experiencing increased severity and frequency of attacks, accompanied by progressive resistance to medical and surgical therapies [37]. 
Pharmacologic treatment is the first line for TN and this is summarized in Table 1. While most evidence of efficacy exists for carbamazepine, a longer acting form of this drug has been shown to be useful for night use to ensure therapeutic serum levels, and decrease side effects from high serum peaks $[38,39]$. For those with significant side effects from carbamazepine, dosage may be reduced and baclofen (50-80 mg daily) may be added as an adjunct. Oxcarbazepine (300-1200 mg daily) is a derivative with fewer side effects and drug interactions than carbamazepine. Among the few studies, it has similar efficacy as carbamazepine and better tolerability [40]. Lamotrigine (400-600 mg daily) has been reported in small case series and a small randomized controlled trial (RCT) as an adjunct

Table 1. Medical management of trigeminal neuralgia: common treatment modalities.

\begin{tabular}{|c|c|c|c|c|}
\hline Drug/procedure/therapy & Author (year) & Efficacy/comments & $\begin{array}{l}\text { Adverse effects/morbidity/ } \\
\text { mortality }\end{array}$ & Ref. \\
\hline \multicolumn{5}{|l|}{ Evidence from RCTs } \\
\hline Baclofen (50-80 mg daily) & $\begin{array}{l}\text { Fromm et al. (1984) } \\
\text { Fromm and Terrence (1987) } \\
\text { Parekh et al. (1989) }\end{array}$ & $\begin{array}{l}\text { Adjunct medication with others } \\
\text { Possibly effective } \\
\text { Three small RCTs }\end{array}$ & $\begin{array}{l}\text { Ataxia, lethargy, fatigue, nausea, } \\
\text { vomiting, loss of muscle tone } \\
\text { Beware of rapid withdrawal }\end{array}$ & $\begin{array}{l}{[24]} \\
{[84]} \\
{[85]}\end{array}$ \\
\hline $\begin{array}{l}\text { Carbamazepine } \\
\text { (300-1000 mg daily) }\end{array}$ & $\begin{array}{l}\text { Campbell et al. (1966) } \\
\text { Killian and Fromm (1968) } \\
\text { Nicol (1969) }\end{array}$ & $\begin{array}{l}\text { NNT } 1.9 \text { ( } 95 \% \text { Cl: 1.4-2.8) } \\
\text { Loses efficacy with time } \\
\text { Requires careful monitoring } \\
\text { for drug interactions, blood } \\
\text { dyscrasias, electrolytes } \\
\text { Introduce slowly }\end{array}$ & $\begin{array}{l}\text { Drowsiness, ataxia, headaches, } \\
\text { poor concentration, nausea, blurred } \\
\text { vision, rash }\end{array}$ & $\begin{array}{l}{[86]} \\
{[87]} \\
{[88]}\end{array}$ \\
\hline $\begin{array}{l}\text { Gabapentin } \\
\text { (300-3600 mg daily) }\end{array}$ & Lemos et al. (2008) & $\begin{array}{l}\text { Evaluated in combination with } \\
\text { ropivacaine only in RCT } \\
\text { (300-900 mg) } \\
\text { NNT } 2.4(95 \% \text { Cl: } 1.46-8.49) \text { in } \\
\text { combination with ropivacaine } \\
\text { Open trials use higher dosages } \\
(1800-3600 \mathrm{mg})\end{array}$ & Sedation, ataxia, dizziness, edema & [89] \\
\hline $\begin{array}{l}\text { Lamotrigine } \\
\text { (200-400 mg daily) }\end{array}$ & Zakrzewska et al. (1997) & $\begin{array}{l}\text { Good when added to other } \\
\text { antiepileptic drug } \\
\text { NNT } 2.1 \text { (95\% CI: } 1.3-6.1) \\
\text { Escalate slowly to avoid rashes }\end{array}$ & $\begin{array}{l}\text { Dizziness, drowsiness, constipation, } \\
\text { ataxia, diplopia, irritability }\end{array}$ & {$[43]$} \\
\hline $\begin{array}{l}\text { Oxcarbazepine } \\
\text { (300-1200 mg daily) }\end{array}$ & $\begin{array}{l}\text { Liebel et al. (2001) } \\
\text { Beydoun and Kutluay (2002) }\end{array}$ & $\begin{array}{l}\text { Equal efficacy to carbamazepine } \\
\text { but better tolerated } \\
\text { Less tendency for blood } \\
\text { dyscrasias } \\
\text { No major drug interactions }\end{array}$ & $\begin{array}{l}\text { Drowsiness, poor concentration, } \\
\text { dizziness, ataxia, nausea } \\
\text { Hyponatremia in high doses }\end{array}$ & $\begin{array}{l}{[90]} \\
{[91]}\end{array}$ \\
\hline \multicolumn{5}{|l|}{ No evidence from RCTs } \\
\hline Clonazepam (4-8 mg daily) & $\begin{array}{l}\text { Caccia (1975) } \\
\text { Chandra (1976) } \\
\text { Court and Kase (1976) } \\
\text { Smirne and Scarlato (1997) }\end{array}$ & $\begin{array}{l}\text { Good to excellent results } \\
\text { reported in small case series } \\
\text { Addictive tendency }\end{array}$ & $\begin{array}{l}\text { Lethargy, dizziness, personality } \\
\text { change } \\
\text { Thrombocytopenia }\end{array}$ & $\begin{array}{l}{[92]} \\
{[93]} \\
{[94]} \\
{[95]}\end{array}$ \\
\hline $\begin{array}{l}\text { Phenytoin } \\
\text { (200-300 mg daily) }\end{array}$ & $\begin{array}{l}\text { lannone et al. (1958) } \\
\text { Braham and Saia (1960) } \\
\text { Chinitz et al. (1966) }\end{array}$ & $\begin{array}{l}\text { Good to excellent results } \\
\text { reported in small case series } \\
\text { Complex pharmacokinetics } \\
\text { preclude large dosage changes }\end{array}$ & $\begin{array}{l}\text { Folate deficiency in prolonged use } \\
\text { Ataxia, lethargy, headache } \\
\text { Gingival hyperplasia }\end{array}$ & $\begin{array}{l}{[96]} \\
{[97]} \\
{[98]}\end{array}$ \\
\hline $\begin{array}{l}\text { Pregabalin } \\
\text { (150-600 mg daily) }\end{array}$ & $\begin{array}{l}\text { Obermann et al. (2008) } \\
\text { Perez et al. (2009) }\end{array}$ & $\begin{array}{l}\text { Overall } 59 \% \text { response rate in } \\
\text { two case series, but results } \\
\text { not sustained } \\
\text { Rapid titration possible and twice } \\
\text { daily dosage }\end{array}$ & $\begin{array}{l}\text { Dizziness, tiredness, headaches, } \\
\text { peripheral edema }\end{array}$ & $\begin{array}{r}{[99]} \\
{[100]}\end{array}$ \\
\hline
\end{tabular}


for subeffective therapy [41-43]. The limited evidence for gabapentin in TN showed best response among patients who used it in combination with a local anesthetic, but the doses used were small and in newly diagnosed patients who may have gone into natural remission. There currently is insufficient evidence showing efficacy of nonantiepileptic drugs (e.g., tizanidine, tocainide or pimozide) for the management of TN [44].

Patients' age, medical status and response to medical therapy factor into making the decision to treat surgically $[45,46]$. However, there is insufficient evidence to determine what is the most effective surgical intervention due to lack of RCTs, cohort studies, uniform criteria and outcome measures [47,48]. Surgery can be carried out at three different levels: peripherally at trigger points; at the Gasserian ganglion level; and at the posterior fossa nerve root level (Table 2).

All peripheral procedures give only temporary relief, and have the goal of inducing localized nerve damage and should be reserved for emergency use or for patients for whom other procedures or treatments are contraindicated. There are no recent high quality studies in this area [48]. Pain relief varies from a few months to 2 years, however, patients often remain on some medication after surgery. Procedures at the Gasserian ganglion level include radiofrequency rhizolysis, glycerol injection or balloon compression. They are all destructive (ablative) and therefore result in varying sensory loss which can affect quality of life.

Surgeries at the posterior fossa nerve root level include stereotactic radiosurgery and microvascular decompression. Stereotactic radiosurgery delivers radiosurgical doses of 70-90 Gray units to the trigeminal nerve root at the point of vascular compression, as mapped using MRI. Pain relief can be delayed for several months and may only be partial. As longer term data from larger centers is being published it appears that the pain relief time is similar to other destructive procedures and sensory loss can occur up to 6 months after treatment [49]. The procedure of microvascular decompression, a major neurosurgical procedure, aims to separate the nerve from the suspected compressing vessel without damage to the nerve itself, and provides the longest period of pain relief with low risk of sensory loss. However, it has a mortality rate and so can only be performed in medically fit patients.
Those patients with multiple sclerosis-related TN are difficult to manage, as their tolerability of drugs is low and recurrence rates are much higher after surgical procedures [45].

Patients value having more information about TN both from healthcare professionals and other patients, and there is evidence that patient support groups are helpful $[35,50]$.

\section{- Trigeminal neuropathic pain (TIN \& AO)}

There is no clear and universally accepted classification system and criteria for continuous trigeminal pain conditions, some of which may be neuropathic in origin. As a result, it is difficult to determine the incidences of pain or sensory loss, and there is a lack of reliable epidemiologic and prognostic data. Some may develop chronic pain due to nerve injury after surgical trauma, such as tooth extraction or root canal therapy, or from more significant injuries such as trauma to the facial skeleton. Although dental surgery and orthognathic surgery is associated with sensory changes, the incidence of chronic pain remains unclear [51]. Persistent pain has been reported after endodontic (root canal) therapy to occur in 3 and $13 \%$ of cases, with significant risk associated with long and more severe preoperative tooth pain, history of chronic pain, previous painful orofacial treatment and female gender [52]. It is now believed that AO may be a subset of trigeminal neuropathic pain, and there are data suggesting that persistent idiopathic facial pain (PIFP; previously known as atypical facial pain) has elements of being a continuous pain condition but with less clear neuroanatomical boundaries [53,54]. Patients with PIFP and AO have been shown with neurophysiological and qualitative physiological tests to have some degree of sensory dysfunction, including peripheral and central sensitization changes and even nociceptive changes [55,56].

The proposed pathophysiology of neuropathic pains of traumatic origin involves inflammatory and physical injury processes both in the PNS and CNS [57,58]. Inflammation occurs in response to nerve injury, which leads to ectopic electrophysiological activity and increased neuronal excitability [59]. Neuroplastic changes occur and continued afferent input leads to peripheral and central sensitization [60]. At the spinal level, a depletion of inhibitory interneurons occurs, and at the supraspinal level there is decreased inhibition and increased 
Table 2. Surgical management of trigeminal neuralgia.

\begin{tabular}{|c|c|c|c|c|}
\hline Procedure/therapy & Author (year) & Efficacy/comments & Adverse effects/morbidity/mortality & Ref. \\
\hline $\begin{array}{l}\text { Peripheral - neurectomy, } \\
\text { cryotherapy, alcohol } \\
\text { injection }\end{array}$ & $\begin{array}{l}\text { Eide et al. (1998) } \\
\text { Fardy et al. (1994) } \\
\text { Erdem and Alkan (2001) } \\
\text { Pradel et al. (2002) }\end{array}$ & $\begin{array}{l}\text { Probability of being pain free after } \\
2 \text { years: } 22 \% \\
\text { Pain often migrates to other branches } \\
\text { necessitating drug use }\end{array}$ & $\begin{array}{l}\text { Transient hematoma, edema } \\
\text { Mild sensory loss, dysesthesia }\end{array}$ & $\begin{array}{l}{[101]} \\
{[102]} \\
{[103]} \\
{[104]}\end{array}$ \\
\hline $\begin{array}{l}\text { Radiofrequency } \\
\text { thermorhizotomy }\end{array}$ & Zakrzewska (1991) & $\begin{array}{l}\text { Probability of being pain free after } \\
2 \text { years: } 68 \% \\
\text { Probability of being pain free after } \\
5 \text { years: } 48 \% \\
\text { Side effects related to temperature used }\end{array}$ & $\begin{array}{l}\text { Sensory loss, dysesthesia, anesthesia } \\
\text { dolorosa } \\
\text { Eye and masticatory problems }\end{array}$ & {$[105]$} \\
\hline $\begin{array}{l}\text { Percutaneous glycerol } \\
\text { rhizotomy }\end{array}$ & Pollock (2005) & $\begin{array}{l}\text { Probability of being pain free after } \\
2 \text { years: } 63 \% \\
\text { Probability of being pain free after } \\
5 \text { years: } 45 \% \\
\text { Technically more demanding than } \\
\text { radiofrequency thermorhizotomy }\end{array}$ & Sensory loss, dysesthesia & [106] \\
\hline $\begin{array}{l}\text { Balloon } \\
\text { microcompression }\end{array}$ & $\begin{array}{l}\text { Lobato et al. (1990) } \\
\text { Correa and Teixeira } \\
\text { (1998) }\end{array}$ & $\begin{array}{l}\text { Probability of being pain free after } \\
2 \text { years: } 79 \%\end{array}$ & $\begin{array}{l}\text { Sensory loss, dysesthesia } \\
\text { Masticatory problems }\end{array}$ & $\begin{array}{l}{[107]} \\
{[108]}\end{array}$ \\
\hline $\begin{array}{l}\text { Microvascular } \\
\text { decompression }\end{array}$ & $\begin{array}{l}\text { Broggi et al. (2000) } \\
\text { Pollock and Ecker (2005) }\end{array}$ & $\begin{array}{l}\text { Probability of being pain free after } \\
2 \text { years: } 81 \% \\
\text { Probability of being pain free after } \\
5 \text { years: } 76 \% \\
\text { Probability of being pain free after } \\
10 \text { years: } 70 \%\end{array}$ & $\begin{array}{l}\text { Perioperative complications (16\%) } \\
\text { Transient cranial nerve dysfunction } \\
\text { (IV, VI, VIII) } \\
\text { Permanent deafness (2\%) } \\
\text { Mortality }(0.2-0.4 \%)\end{array}$ & $\begin{array}{l}{[109]} \\
{[110]}\end{array}$ \\
\hline $\begin{array}{l}\text { Gamma knife stereotactic } \\
\text { radiosurgery }\end{array}$ & Flickinger et al. (2001) & $\begin{array}{l}\text { Probability of being pain free after } \\
2 \text { years: } 58 \% \\
\text { Late onset of relief } \\
\text { May only be partial relief }\end{array}$ & Sensory loss (7\%) & [111] \\
\hline
\end{tabular}

facilitation of pain mechanisms [61,62]. The net result of these processes are hyperalgesia, hypersensitivity and allodynia.

The general characteristics of trigeminal neuropathic pain include continuous burning pain, which may accompany paroxysms that are either evoked or spontaneous. Pain is of moderate to severe intensity, and can be accompanied by other sensory dysfunction such as hypoesthesia or numbness, and dysesthesia. The pain is in a neuroanatomically defined area, either corresponding to a peripheral or central innervation territory. Patients may complain of swelling or the feeling of swelling, a foreign body, hot or cold, local redness or flushing.

Trigeminal neuropathic pain, TIN and AO have pain that is unilateral, corresponds to a dermatome, or may spread across dermatomes, depending on the extent of trauma. For posttraumatic neuropathic pain, a history of previous dental treatment or trauma (i.e., suggested that this is within 3 months [12]) precedes pain onset, and may be accompanied by partial or complete sensory loss in the affected region. However, confirmation of a nerve lesion or disease by a specific test, study or surgical exploration is often impossible.

Diagnosis is based on a thorough history and careful examination, consisting of a neurologic examination, dental examination and evaluation of the temporomandibular joint and musculature. Quantitative sensory testing and other neurophysiologic tests (e.g., blink reflex) may help distinguish traumatically induced or localized neuropathic pain from PIFP, however, there is considerable overlap in abnormalities between the two, and such tests are only available in specialist centers [55]. Imaging studies may be warranted to rule out central processes such as tumor, vascular compression and infection.

Most of the accepted management of these conditions is based on expert opinion and case reports. Of the few RCTs, one for the treatment of AO comparing local anesthesia versus a placebo of normal saline showed some but not complete pain relief with the anesthetic [63]. Another RCT 
found that intravenous infusion of ketamine and fentanyl was unable to produce an analgesic effect on spontaneous pain, but fentanyl reduced pain evoked by capsaicin [64]. Choices of medication should be based on proposed physiology, presence of other comorbidities and the patient's use of other medications. Current accepted therapies are based on evidence and general guidelines for other neuropathic pain conditions and are summarized in Table 3. For trigeminal neuropathic pain the consensus is that tricyclic antidepressants, especially nortriptyline, and calcium channel blockers ( $\alpha 2 \delta$ ligand modulators) such as gabapentin and pregabalin should be first-line therapies. Controversy does exist regarding the validity of evidence on gabapentin for off-label use with issues ranging from questionable and biased outcome reporting, to aggressive marketing by its manufacturer $[65,66]$. Selective serotonin/norepinephrine reuptake inhibitors and specific selective norepinephrine reuptake inhibitors are considered as second-line therapies [67]. By contrast, selective serotonin reuptake inhibitors have been found to have less efficacy, and has the undesired side effect of bruxism [68,69]. Opioids and tramadol are considered to be third-line therapies, considering the overlap of both neuropathic and nociceptive mechanisms in trigeminal neuropathic pain, however, they should only be used on a limited basis with close monitoring by the prescribing provider. Topical medicaments have been advocated as first-line treatments for peripheral neuropathic pain, due to a lack of systemic side effects. They may be delivered to the injured or affected sites with the aid of shields or custom made intraoral stents made of a soft splint material. In open labeled studies, topical amitriptyline was effective in peripheral neuropathic pain, and capsaicin $0.025 \%$ cream was effective in oral neuropathic pain and traumautic trigeminal dysesthesias [70,71]. The lidocaine patch (5\%) has been shown in RCTs to be effective in the treatment of postherpetic neuralgia with minimal risk of side effects [72].

Table 3. Medical management of trigeminal neuropathic pain, based on guidelines for general neuropathic pain conditions.

\begin{tabular}{|c|c|c|c|c|}
\hline Drug/procedure/therapy & Author (year) & Efficacy/comments & Adverse effects/morbidity/mortality & Ref. \\
\hline \multicolumn{5}{|l|}{ Tricyclic antidepressants } \\
\hline $\begin{array}{l}\text { Nortriptyline ( } 25-150 \text { mg daily) } \\
\text { Amitriptyline ( } 25-150 \text { mg daily) } \\
\text { Imipramine ( } 25-150 \text { mg daily) }\end{array}$ & $\begin{array}{l}\text { Kishore-Kumar et al. (1990) } \\
\text { Watson et al. (1982) } \\
\text { Graff-Radford et al. (2000) }\end{array}$ & $\begin{array}{l}\text { Proven in RCTs } \\
\text { Low cost } \\
\text { Doses on average } 40 \mathrm{mg} \\
\text { Minimum 6-8 weeks } \\
\text { Nortriptyline commonly used as } \\
\text { fewer oral side effects }\end{array}$ & $\begin{array}{l}\text { Sedation, dry mouth, weight gain } \\
\text { Care in cardiac disease }\end{array}$ & $\begin{array}{l}{[112]} \\
{[113]} \\
{[114]}\end{array}$ \\
\hline Duloxetine (30-120 mg daily) & $\begin{array}{l}\text { Goldstein et al. (2005) } \\
\text { Raskin et al. (2005) }\end{array}$ & $\begin{array}{l}\text { Twice daily for } 4 \text { weeks } \\
\text { Not reported in facial pain }\end{array}$ & Nausea & $\begin{array}{l}{[115]} \\
{[116]}\end{array}$ \\
\hline Venlafaxine (37.5-225 mg daily) & Forssell et al. (2004) & $\begin{array}{l}\text { Daily for } 4-6 \text { weeks } \\
\text { Venlafaxine had no benefit in } \\
\text { small RCT for facial pain }\end{array}$ & & {$[117]$} \\
\hline Pregabalin (300-600 mg daily) & $\begin{array}{l}\text { Frampton and Foster } \\
(2005)\end{array}$ & $\begin{array}{l}\text { Twice daily for } 4 \text { weeks } \\
\text { Useful in those with concomitant } \\
\text { anxiety }\end{array}$ & & [119] \\
\hline Tramadol (100-400 mg daily) & $\begin{array}{l}\text { Norrbrink and Lundeberg } \\
\text { (2009) }\end{array}$ & Rarely used in trigeminal pain & Sedation, nausea, constipation & {$[120]$} \\
\hline Topical (5\% lidocaine patch) & Davies and Galer (2004) & $\begin{array}{l}\text { RCTs show efficacy for } \\
\text { postherpetic neuralgia } \\
\text { Difficult to apply on the face } \\
\text { Three patches and } 12 \mathrm{~h} \text { maximum } \\
\text { Use for } 3 \text { weeks }\end{array}$ & Erythema, rash & [72] \\
\hline
\end{tabular}


The role of surgical interventions for trigeminal neuropathies remains unclear due to a lack of good evidence with prospective controlled trials. Sympathetic blockade and sympathetic radiofrequency remain unproven, and their use may be ineffectual due to recent findings showing a lack of activation of nociceptors related to sympathetic discharge in chronic neuropathic pain patients [73]. Other proposed surgical interventions include using a gamma knife that targets the sphenopalatine ganglion and brain stimulation. Noninvasive electrical brain stimulation techniques, including magnetic, electrical and direct current stimulation, have been shown to be effective for certain chronic pain conditions and may have applicability [74].

\section{Burning mouth syndrome}

Burning mouth syndrome (also known as stomatodynia) is an oral mucosal pain condition that is chronic, and absent of identifiable causative lesions, conditions or diseases. Reported prevalence in general populations varies from 1 to $15 \%$ according to diagnostic criteria, however, many studies include people with the symptom of burning mouth rather than true BMS as defined above [75].

Once thought to be purely psychologic in etiology, there is now increasing evidence of neuropathic elements of this disorder [76]. Supporting that hypothesis is the frequent presence of dysgeusia with pain in BMS patients. The taste nervous system is thought to provide central inhibitory control over afferent fibers responsible for pain in both the glossopharyngeal and trigeminal nerves. This is supported by the findings that anesthesia of the chorda tympani causes increased pain evoked by capsaicin on the contralateral anterior tongue, topical administration of lidocaine to affected areas increases oral burning, in the same manner as in phantom limb pain, and hypofunction of the chorda tympani can lead to taste disturbance [77]. A relation has been established between the genetic predisposition of 'supertasters', with the ability to elicit a bitter taste sensation with 6-n-propyl-thiouracil, and intensification of pain. There is also a thought that dysregulation, impairment or decrease of sitespecific (i.e., oral) neuroactive steroids that have a neuroprotective effect, results in symptomatology of BMS [78]. This may account for the predilection towards postmenopausal women and for the comorbidities of stress, anxiety and depression among BMS patients, all factors that change adrenal production of steroids.

Women are three- to 20-fold more affected than men, usually at menopausal or postmenopausal age. Onset is spontaneous, with constant burning sensation and no paroxysmal components. This may be accompanied by tingling, dyesthesias and dysgeusia (altered taste). Location is mainly bilateral, with anterior tongue involvement in most cases, but also the lips, palate and pharynx can be involved. Pain intensity is variable among patients, ranging from both extremes in the spectrum from mild discomfort, to excruciating pain. Patients often report high scores in psychometric tests for anxiety and depression, but no causal relationship has been found. There is no precise information on the clinical course and prognosis of BMS. Improvement has been cited in one-half to two-thirds of patients within 6-7 years of onset, with spontaneous remission rates of $20 \%$ in that time frame $[76,79]$. One clinical study found spontaneous remission to occur in 3\% of patients within 5 years after diagnosis $[76,80]$.

Diagnosis is obtained based on a thorough history and the elimination of local (e.g., candidiasis, herpes, hyposalivation, allergy, mucosal lesions) or systemic factors (e.g., vitamin deficiencies, diabetes, hypothyroidism, medications [e.g., angiotensin-converting enzyme inhibitors], autoimmune disorders) as causes of their symptoms. Diagnostic tests include blood tests (i.e., hematological, biochemical and immunologic) and microbial testing (i.e., viral or fungal culture).

There are very few RCTs for BMS, as summarized in Table $4[81,82]$. Upon diagnosis of BMS, patients should be reassured about the physiological basis of their condition despite lack of identifiable organic causes, and that it is not due to malignant processes. Treatment for BMS is primarily pharmacological, with psychological support if indicated in refractory cases with high anxiety or depression. One controlled study showed that cognitive behavioral therapy of weekly $1 \mathrm{~h}$ sessions for 4 months reduced pain intensity for up to 6 months in BMS patients [83], however, no other studies on this approach have been published in recent years.

\section{Conclusion \& future perspective}

Although therapies for trigeminal neuropathic pains should be targeted towards specific mechanisms, uncertainties preclude definite 
Table 4. Management of burning mouth syndrome.

\begin{tabular}{|c|c|c|c|c|}
\hline Drug/procedure/therapy & Author (year) & Efficacy/comments & Adverse effects/morbidity/mortality & Ref. \\
\hline \multicolumn{5}{|l|}{ Evidence from RCTs } \\
\hline $\begin{array}{l}\alpha \text {-lipoic acid } \\
(200-600 \text { mg daily) }\end{array}$ & $\begin{array}{l}\text { Femiano et al. (2000) } \\
\text { Femiano et al. (2002) } \\
\text { Femiano and Scully (2002) } \\
\text { Femiano et al. (2004) }\end{array}$ & $\begin{array}{l}\text { Use daily for } 3 \text { months } \\
\text { NNT 1.6-3.3 } \\
\text { Earlier trials from same center and not } \\
\text { all double blind } \\
\text { Newer RCT shows no benefit }\end{array}$ & None reported & $\begin{array}{l}{[121]} \\
{[122]} \\
{[123]} \\
{[124]}\end{array}$ \\
\hline $\begin{array}{l}\text { Capsaicin systemic } \\
(0.25 \% \text { capsule } \\
\text { three-times daily) }\end{array}$ & Petruzzi et al. (2004) & $\begin{array}{l}\text { NNT 1-2 } \\
\text { Poor quality trial } \\
\text { Side-effect profile limits its use }\end{array}$ & Gastric pain in $32 \%$ & [126] \\
\hline \multicolumn{5}{|l|}{ SSRIS } \\
\hline $\begin{array}{l}\text { Cognitive behavior } \\
\text { therapy }\end{array}$ & Bergdahl et al. (1995) & $\begin{array}{l}1 \mathrm{~h} \text { for } 12-15 \text { weeks } \\
\text { Single-blind } \mathrm{RCT} \\
\text { More effective than no treatment }\end{array}$ & & {$[83]$} \\
\hline \multicolumn{5}{|l|}{ No evidence from RCTs } \\
\hline \multicolumn{5}{|c|}{ Calcium channel blockers ( $\alpha 2 \delta$ ligand modulators) } \\
\hline $\begin{array}{l}\text { Gabapentin } \\
\text { (300-2400 mg daily) }\end{array}$ & $\begin{array}{l}\text { White et al. (2004) } \\
\text { Heckmann et al. (2006) }\end{array}$ & Limited effectiveness & $\begin{array}{l}\text { Ataxia, dizziness, drowsiness, nausea, } \\
\text { headache, weight gain } \\
\text { Care in renal dysfunction }\end{array}$ & $\begin{array}{l}{[128]} \\
{[129]}\end{array}$ \\
\hline $\begin{array}{l}\text { Pregabalin } \\
\text { (100-300 mg daily) }\end{array}$ & Lopez et al. (2009) & $\begin{array}{l}\text { May be effective } \\
\text { Improves anxiety and sleep }\end{array}$ & $\begin{array}{l}\text { Dizziness, tiredness, headaches, } \\
\text { peripheral edema } \\
\text { Care in renal dysfunction }\end{array}$ & [130] \\
\hline
\end{tabular}

treatment algorithms. Therefore, there is a need to further define pathophysiology of trigeminal neuropathic pains, with the idea that multiple mechanisms might be involved. In addition, consistent classification, taxonomy, criteria, phenotyping and definitions of outcome measures of the various conditions are needed in order to carry out clinical trials. Among clinical trials, there is a need for comparisons of different medications available, both individually and in combinations. Providers must translate the effectiveness of clinical trials into their practice, as often noneffective medications, subtherapeutic dosages or inadequate times for trial therapy lead to treatment failure, and ultimately frustration on the part of providers and patients. In addition, patient education and supportive adjunctive therapies and measures should be emphasized and included in the overall treatment plan. Patient understanding and informed reassurance of their condition leads to better management, with improved coping strategies, more compliance and proper utilization of treatment modalities.

Financial \& competing interests disclosure

$J$ Zakrzewska has received an investigator-led grant from UCB Pharma for a study on leviteracetam. J Zakrzewska undertook this work at UCL/UCLHT, who received a proportion of funding from the Department of Health's NIHR Biomedical Research Center funding scheme. The authors have no other relevant affiliations or financial involvement with any organization or entity with a financial interest in or financial conflict with the subject matter or materials discussed in the manuscript apart from those disclosed.

No writing assistance was utilized in the production of this manuscript. 


\section{Bibliography}

Papers of special note have been highlighted as:

- of interest

-. of considerable interest

1 Treede RD, Jensen TS, Campbell JN et al. Neuropathic pain: redefinition and a grading system for clinical and research purposes. Neurology 70(18), 1630-1635 (2008).

2 Fried K, Bongenhielm U, Boissonade FM, Robinson PP. Nerve injury-induced pain in the trigeminal system. Neuroscientist 7(2), 155-165 (2001).

3 Finnerup NB, Sindrup SH, Jensen TS. Chronic neuropathic pain: mechanisms, drug targets and measurement. Fundam. Clin. Pharmacol. 21(2), 129-136 (2007).

- Important overview.

4 Clark JD. Chronic pain prevalence and analgesic prescribing in a general medical population. J. Pain Symptom Manage. 23(2), 131-137 (2002).

5 Hasselstrom J, Liu-Palmgren J, Rasjo-Wraak G. Prevalence of pain in general practice. Eur. J. Pain 6(5), 375-385 (2002).

6 Koleva D, Krulichova I, Bertolini G, Caimi V, Garattini L. Pain in primary care: an Italian survey. Eur. J. Public Health 15(5), 475-479 (2005).

7 McDermott AM, Toelle TR, Rowbotham DJ, Schaefer CP, Dukes EM. The burden of neuropathic pain: results from a cross-sectional survey. Eur. J. Pain 10(2), 127-135 (2006).

8 Meyer-Rosberg K, Kvarnstrom A, Kinnman E, Gordh T, Nordfors LO, Kristofferson A. Peripheral neuropathic pain - a multidimensional burden for patients. Eur. J. Pain 5(4), 379-389 (2001).

9 Headache Classification Subcommittee of the International Headache Society. The International Classification of Headache Disorders (2nd Edition). Cephalalgia 24(Suppl. 1), 9-160 (2004).

10 Olesen J. The future of headache classification and classification research. Cephalalgia 29(12), 1240-1241 (2009).

11 Olesen J. New plans for headache classification: ICHD-3. Cephalalgia 31(1), 4-5 (2011).

12 Orofacial Pain and Headache. Sharav Y, Benoliel R (Ed.). Elsevier, London, UK (2008).

13 Nixdorf DR, Drangsholt M, Ettlin DA et al. Classifying orofacial pains: developing a taxonomy using ontological principles. J. Oral Rehab. (2011) (In Press).
14 Treede RD, Jensen TS, Campbell JN et al. Neuropathic pain: redefinition and a grading system for clinical and research purposes. Neurology 70 (18), 1630-1635 (2008).

15 Forssell H, Jaaskelainen S, Tenovuo O, Hinkka S. Sensory dysfunction in burning mouth syndrome. Pain 99(1-2), 41-47 (2002).

16 Cohen AS, Matharu MS, Goadsby PJ. Trigeminal autonomic cephalalgias: current and future treatments. Headache 47(6), 969-980 (2007).

- Good overview of these conditions (mentioned, but not discussed in this article).

17 Olesen J, Bousser M-G, Diener HC et al. The International Classification of Headache Disorders (2nd Edition). Cephalgia 24(Suppl. 1), 24-150 (2004).

18 Zakrzewska JM, Hamlyn PJ: Facial pain. In: Epidemiology of Pain: A Report of the Task Force on Epidemiology (1st Edition). Crombie IKCPR, Linton SJ, LeResche L, Von Korff M (Eds). IASP Press, Seattle, USA, 171-202 (1999).

19 Koopman JS, Dieleman JP, Huygen FJ, de Mos M, Martin CG, Sturkenboom MC. Incidence of facial pain in the general population. Pain 147(1-3), 122-127 (2009).

-1 Shows the high frequency of misdiagnosis of trigeminal neuralgia.

20 Hall GC, Carroll D, Parry D, McQuay HJ. Epidemiology and treatment of neuropathic pain: the UK primary care perspective. Pain 122(1-2), 156-162 (2006).

21 Peker S, Dincer A, Necmettin Pamir M. Vascular compression of the trigeminal nerve is a frequent finding in asymptomatic individuals: 3-T MR imaging of 200 trigeminal nerves using 3D CISS sequences. Acta Neurochir. (Wien) 151(9), 1081-1088 (2009).

22 Ishikawa M, Nishi S, Aoki T et al. Operative findings in cases of trigeminal neuralgia without vascular compression: proposal of a different mechanism. J. Clin. Neurosci. 9(2), 200-204 (2002).

23 Devor M, Amir R, Rappaport ZH. Pathophysiology of trigeminal neuralgia: the ignition hypothesis. Clin. J. Pain 18(1), 4-13 (2002).

-1 Most widely accepted hypothesis of trigeminal neuralgia. However, with the absence of data in human subjects this theory has been questioned and challenged.

24 Fromm GH, Terrence CF, Maroon JC. Trigeminal neuralgia. Current concepts regarding etiology and pathogenesis. Arch. Neurol. 41(11), 1204-1207 (1984).
25 Dubner R, Sharav Y, Gracely RH, Prince DD. Idiopathic trigeminal neuralgia: sensory features and pain mechanisms. Pain 31(1), 23-33 (1987).

26 Moisset X, Villain N, Ducreux D et al. Functional brain imaging of trigeminal neuralgia. Eur. J. Pain 15(2), 124-131 (2011).

27 King RB. Evidence for a central etiology of tic douloureux. J. Neurosurg. 26(1), 175-180 (1967).

28 Greenwood LF, Sessle BJ. Inputs to trigeminal brain stem neurons from facial, oral, tooth, pulp and pharyngolaryngeal tissues: II. Role of trigeminal nucleus caudalis in modulating responses to innocuous and noxious stimuli. Brain Res. 117(2), 227-238 (1976).

29 Obermann M, Yoon MS, Ese D et al. Impaired trigeminal nociceptive processing in patients with trigeminal neuralgia. Neurology 69(9), 835-841 (2007).

- First publication looking at this aspect of trigeminal neuralgia.

30 Bowsher D. Trigeminal neuralgia: a symptomatic study of 126 successive patients with and without previous interventions. Pain Clinic 12(2), 93-98 (2000).

31 Limonadi FM, McCartney S, Burchiel KJ. Design of an artificial neural network for diagnosis of facial pain syndromes. Stereotact. Funct. Neurosurg. 84(5-6), 212-220 (2006).

32 Zakrezewska JM, Linskey ME. Trigeminal neuralgia. In: Orofacial Pain (1st Edition). Zakrzewska JM (Ed.). Oxford University Press, Oxford, UK, 83-92 (2009).

33 Tolle T, Dukes E, Sadosky A. Patient burden of trigeminal neuralgia: results from a crosssectional survey of health state impairment and treatment patterns in xix European countries. Pain Pract. 6(3), 153-160 (2006).

34 Zakrzewska JM, Sawsan J, Bulman JS. A prospective, longitudinal study on patients with trigeminal neuralgia who underwent radiofrequency thermocoagulation of the Gasserian ganglion. Pain 79(1), 51-58 (1999).

- Only cohort study on patients undergoing surgery that includes mood assessment.

35 Insights: Facts and Stories Behind Trigeminal Neuralgia. Zakrzewska JM (Ed.). Trigeminal Neuralgia Association, Gainesville, FL, USA, 1-403 (2006).

- Primarily written for patients, however, useful for clinicians to understand impact on patients.

36 Rozen TD. Trigeminal neuralgia and glossopharyngeal neuralgia. Neurol. Clin. N. Am. 22(1), 185-206 (2004). 
37 Zakrzewska JM, Patsalos PN. Long-term cohort study comparing medical (oxcarbazepine) and surgical management of intractable trigeminal neuralgia. Pain 95(3), 259-266 (2002).

-. One of the few long-term cohort studies for trigeminal neuralgia.

38 Wiffen PJ, Derry S, Moore RA, McQuay HJ. Carbamazepine for acute and chronic pain in adults. Cochrane Database Syst. Rev. 1, CD005451 (2011).

- High-quality systematic review.

39 Miller AD, Krauss GL, Hamzeh FM. Improved CNS tolerability following conversion from immediate-to extend-release carbamazepine. Acta Neurol. Scand. 109(6), 374-377 (2004).

40 Beydoun A, Schmidt D, D'Souza J. Oxcarbazepine versus carbamazepine in trigeminal neuralgia: a meta-analysis of three double blind comparative trials. Neurology 3(Suppl.), 2 (2002)

41 Canavero S, Bonicalzi V, Ferroli P, Zerne S, Montalenti E, Benna P. Lamotrigine control of idiopathic trigeminal neuralgia [letter]. J. Neurol. Neurosurg. Psychiatry 59(6), 646 (1995).

42 Lunardi G, Leandri M, Albano C et al. Clinical effectiveness of lamotrigine and plasma levels in essential and symptomatic trigeminal neuralgia. Neurology 48(6), 1714-1717 (1997)

43 Zakrzewska JM, Chaudhry Z, Nurmikko TJ, Patton DW, Mullens EL. Lamotrigine (lamictal) in refractory trigeminal neuralgia: results from a double-blind placebo controlled crossover trial. Pain 73(2), 223-230 (1997).

44 Yang M, Zhou M, He L et al. Non-antiepileptic drugs for trigeminal neuralgia. Cochrane Database Syst. Rev. 1, CD004029 (2011).

- High-quality systematic review.

45 Cruccu G, Gronseth G, Alksne J et al. AAN-EFNS guidelines on trigeminal neuralgia management. Eur. J. Neurol. 15(10), 1013-1028 (2008).

- Important guidelines across two societies, and published in both respective journals.

46 Gronseth G, Cruccu G, Alksne J et al. Practice parameter: the diagnostic evaluation and treatment of trigeminal neuralgia (an evidence-based review): report of the Quality Standards Subcommittee of the American Academy of Neurology and the European Federation of Neurological Societies. Neurology 71(15), 1183-1190 (2008).

-. Important guidelines across two societies, and published in both respective journals.
47 Zakrzewska JM, Lopez BC. Quality of reporting in evaluations of surgical treatment of trigeminal neuralgia: recommendations for future reports. Neurosurgery 53(1), 110-120 (2003).

48 Zakrzewska JM. Surgery for trigeminal neuralgia? Pain 152(3), 469-470 (2011).

49 Kano H, Kondziolka D, Yang HC et al. Outcome predictors after gamma knife radiosurgery for recurrent trigeminal neuralgia. Neurosurgery 67(6), 1637-1644 (2010).

50 Zakrzewska JM, Jorns TP, Spatz A. Patient led conferences - who attends, are their expectations met and do they vary in three different countries? Eur. J. Pain 13(5), 486-491 (2009).

51 Berge TI. Incidence of chronic neuropathic pain subsequent to surgical removal of impacted third molars. Acta Odontol. Scand. 60(2), 108-112 (2002).

52 Polycarpou N, Ng YL, Canavan D, Moles DR, Gulabivala K. Prevalence of persistent pain after endodontic treatment and factors affecting its occurrence in cases with complete radiographic healing. Int. Endod. J. 38(3), 169-178 (2005).

53 Baad-Hansen L. Atypical odontalgia pathophysiology and clinical management. J. Oral Rehabil. 35(1), 1-11 (2008).

54 List T, Leijon G, Helkimo M, Oster A, Dworkin SF, Svensson P. Clinical findings and psychosocial factors in patients with atypical odontalgia: a case-control study. J. Orofac. Pain 21(2), 89-98 (2007).

- Well conducted study attempting to define this group.

55 Forssell H, Tenovuo O, Silvoniemi P, Jaasklainen SK. Differences and similarities between atypical facial pain and trigeminal neuropathic pain. Neurology 69(14), 1451-1459 (2007).

- Carefully conducted study.

56 Baad-Hansen L, List T, Kaube H, Jensen TS, Svensson P. Blink reflexes in patients with atypical odontalgia and matched healthy controls. Exp. Brain Res. 172(4), 498-506 (2006).

57 Julius D, Basbaum AI. Molecular mechanisms of nociception. Nature 413(6852), 203-210 (2001).

58 Devor M, Seltzer Z. Pathophysiology of damaged nerves in relation to chronic pain. In: Pain. Wall PD, Melzack R (Eds). Churchill Livingstone, London, UK (1999)

59 Eliav E, Benoliel R, Tal M. Inflammation with no axonal damage of the rat saphenous nerve trunk induces ectopic discharge and mechanosensitivity in myelinated axons. Neurosci. Lett. 311(1), 49-52 (2001).

60 Woolf CJ, Salter MW. Neuronal plasticity: increasing the gain in pain. Science 288(5472), 1765-1769 (2000).

61 Moore KA, Hohno T, Karchewski LA, Scholz J, Baba H, Woolf CJ. Partial peripheral nerve injury promotes a selective loss of GABAergic inhibition in the superficial dorsal horn of the spinal cord. J. Neurosci. 22(15), 6724-6731 (2002).

62 Porreca F, Ossipov MH, Gebhart GF. Chronic pain and medullary descending facilitation. Trends Neurosci. 25(6), 319-325 (2002).

63 List T, Leijon G, Helkimo M, Oster A, Svensson P. Effect of local anesthesia on atypical odontalgia - a randomized controlled trial. Pain 122(3), 306-314 (2006).

- Carefully conducted study.

64 Baad-Hansen L, Juhl GI, Jensen TS, Brandsborg B, Svensson P. Differential effect of intravenous S-ketamine and fentanyl on atypical odontalgia and capsaicin-evoked pain. Pain 129(1-2), 46-54 (2007).

65 Landefeld CS, Steinman MA. The Neurontin legacy - marketing through misinformation and manipulation. N. Engl. J. Med. 360 (2), 103-106 (2009).

66 Vedula SS, Bero L, Scherer RW, Dickersin K. Outcome reporting in industry-sponsored trials of gabapenitn for off-label use. $N$. Engl. J. Med. 361(20), 1963-1971 (2009).

67 O'Connor AB, Dworkin RH. Treatment of neuropathic pain: an overview of recent guidelines. Am. J. Med. 122(Suppl. 10), S22-S32 (2009).

-1 Useful overview summarizing recent guideline publications.

68 Otto M, Bach FW, Jensen TS, Brosen K, Sindrup SH. Escitalopram in painful polyneuropathy: a randomized, placebocontrolled cross-over trial. Pain 139(2), 275-283 (2008).

69 Gerber PE, Lynd LD. Selective serotoninreuptake inhibitor-induced movement disorders. Ann. Pharmacother. 32(6), 692-698 (1998).

70 Lynch ME, Clark AJ, Sawynok J, Sullivan MJ. Topical amitriptyline and ketamine in neuropathic pain syndromes: an open-label study. J. Pain 6(10), 644-649 (2005).

71 Canavan D, Graff-Radford SB, Gratt BM. Traumatic dysesthesia of the trigeminal nerve. J. Orofac. Pain 8(4), 391-396 (1994). 
72 Davies PS, Galer BS. Review of lidocaine patch $5 \%$ studies in the treatment of postherpetic neuralgia. Drugs 64(9), 937-947 (2004).

73 Campero M, Bostock H, Baumann TK, Ochoa JL. A search for activation of C nociceptors by sympathetic fibers in complex regional pain syndrome. Clin. Neurophysiol. 121(7), 1072-1079 (2010).

74 O'Connell NE, Wand BM, Marston L, Spencer S, Desouza LH. Non-invasive brain stimulation techniques for chronic pain. Cochrane Database Syst. Rev. 8(9), CD008208 (2010).

75 Tammiala-Salonen T, Hiidenkari T, Parvinen T. Burning mouth in a Finnish adult population. Community Dent. Oral Epidemiol. 21(2), 67-71 (1993).

76 Woda A, Grushka M. Burning mouth syndrome. In: Orofacial Pain (1st Edition). Zakrzewska JM (Ed.). Oxford University Press, Oxford, UK, 83-92 (2009).

- Useful overview and introduction to the topic.

77 Eliav E, Kamran B, Schaham R, Czerninski R, Gracely RH, Benoliel R. Evidence of chorda tympani dysfunction in patients with burning mouth syndrome. J. Am. Dent. Assoc. 138(5), 628-633 (2007).

78 Woda A, Dao T, Gremeau-Richard C. Steroid dysregulation and stomatodynia (burning mouth syndrome). J. Orofac. Pain 23(3), 202-210 (2009).

79 Bergdahl M, Bergdahl J. Burning mouth syndrome: prevalence and associated factors. J. Oral Pathol. Med. 28(8), 350-354 (1999).

80 Sardella A, Lodi G, Demarosi F, Bez C, Cassano S, Carrassi A. Burning mouth syndrome: a retrospective study investigating spontaneous remission and response to treatments. Oral Dis. 12(2), 152-155 (2006).

81 Buchanan J, Zakrzewska J. Burning mouth syndrome. Clin. Evid. (Online) 14, 1301 (2008).

82 Zakrzewska JM, Forssell H, Glenny AM. Interventions for the treatment of burning mouth syndrome. Cochrane Database Syst. Rev. 1, CD002779 (2005).

- Systematic review for treatment of burning mouth syndrome.

83 Bergdahl J, Anneroth G, Perris H. Cognitive therapy in the treatment of patients with resistant burning mouth syndrome: a controlled study. J. Oral Pathol. Med. 24(5), 213-215 (1995).
84 Fromm GH, Terrence CF. Comparison of L-baclofen and racemic baclofen in trigeminal neuralgia. Neurology 37(11), 1725-1728 (1987).

85 Parekh S, Shah K, Kotdadawalla H, Gandhi I. Baclofen in carbamazepine resistant trigeminal neuralgia: double-blind study and long-term follow up. Ann. Neurol. 9, 392-393 (1989).

86 Campbell FG, Graham JG, Zilkha KJ. Clinical trial of carbamazepine (tegretol) in trigeminal neuralgia. J. Neurol. Neurosurg. Psychiatry 29(3), 265-267 (1966).

87 Killian JM, Fromm GH. Carbamazepine in the treatment of neuralgia. Arch. Neurol. 19(2), 129-136 (1968).

88 Nicol CF. A four year double-blind study of tegretol in facial pain. Headache 9 (1), 54-57 (1969).

89 Lemos L, Flores S, Oliveira P, Almeida A. Gabapentin supplemented with ropivacain block of trigger points improves pain control and quality of life in trigeminal neuralgia patients when compared with gabapentin alone. Clin. J. Pain 24(1), 64-75 (2008).

90 Liebel JT, Menger N, Langohr H. Oxcarbazepine in der behandlung der trigeminusneuralgie. Nervenheilkunde 20, 461-465 (2001).

91 Beydoun A, Kutluay E. Oxcarbazepine. Expert Opin. Pharmacother. 3(1), 59-71 (2002).

92 Caccia MR. Clonazepam in facial neuralgia and cluster headache. Clinical and electrophysiological study. Eur. Neurol. 13(6), 560-563 (1975).

93 Chandra B. The use of clonazepam in the treatment of tic douloureux (a preliminary report). Proc. Aust. Assoc. Neurol. 13, 119-122 (1976).

94 Court JE, Kase CS. Treatment of tic douloureux with a new anticonvulsant (clonazepam). J. Neurol. Neurosurg. Psychiatry 39(3), 297-299 (1976).

95 Smirne S, Scarlato G. Clonazepam in cranial neuralgias. Med. J. Aust. 1(4), 93-94 (1977).

96 Iannone A, Baker AB, Morrell F. Dilantin in the treatment of trigeminal neuralgia. Neurology 8(2), 126-128 (1958).

97 Braham J, Saia A. Phenytoin in the treatmen of trigeminal and other neuralgias. Lancet 2 , 892-893 (1960).

98 Chinitz A, Seelinger DF, Greenhouse AH. Anticonvulsant therapy in trigeminal neuralgia. Am. J. Med. Sci. 252(1), 62-67 (1966).
99 Obermann M, Yoon MS, Sensen K, Maschke M, Diener HC, Katsarava Z. Efficacy of pregabalin in the treatment of trigeminal neuralgia. Cephalgia 28(2), 174-181 (2008).

100 Perez C, Navarro A, Saldana MT, Martinez S, Rejas J. Patient-reported outcomes in subjects with painful trigeminal neuralgia receiving pregabalin: evidence from medical practice in primary care settings. Cephalgia 29(7), 781-790 (2009).

101 Eide PK, Rabben T, Skjelbred P, Stubhaug A. The effect of peripheral glycerol on trigeminal neuropathic pain examined by quantitative assessment of abnormal pain and sensory perception. Acta Neurochir. (Wien) 140 (12), 1271-1277 (1998).

102 Fardy MJ, Zakrzewska JM, Patton DW. Peripheral surgical techniques for the management of trigeminal neuralgia - alcohol and glycerol injections. Acta Neurochir. (Wien) 129(3-4), 181-184 (1994).

103 Erdem E, Alkan A. Peripheral glycerol injections in the treatment of idiopathic trigeminal neuralgia: retrospective analysis of 157 cases. J. Oral Maxillofac. Surg. 59(10), 1176-1180 (2001).

104 Pradel W, Hlawitschka M, Eckelt U, Herzog R, Koch K. Cryosurgical treatment of genuine trigeminal neuralgia. $\mathrm{Br}$. J. Oral Maxillofac. Surg. 40(3), 244-247 (2002).

105 Zakrzewska JM. Cryotherapy for trigeminal neuralgia: a 10 year audit. Br. J. Oral Maxillofac. Surg. 29(1), 1-4 (1991).

106 Pollock BE. Percutaneous retrogasserian glycerol rhizotomy for patients with idiopathic trigeminal neuralgia: a prospective analysis of factors related to pain relief. J. Neurosurg. 102(2), 223-228 (2005).

107 Lobato RD, Rivas JJ, Sarabia R, Lamas E. Percutaneous microcompression of the gasserian ganglion for trigeminal neuralgia. J. Neurosurg. 72(4), 546-553 (1990).

108 Correa CF, Teixeira MJ. Balloon compression of the Gasserian ganglion for the treatment of trigeminal neuralgia. Stereotact. Funct. Neurosurg. 71(2), 83-89 (1998).

109 Broggi G, Ferroli P, Franzini A, Servello D, Dones I. Microvascular decompression for trigeminal neuralgia: comments on a series of 250 cases, including 10 patients with multiple sclerosis. J. Neurol. Neurosurg. Psychiatry 68(1), 59-64 (2000).

110 Pollock BE, Ecker RD. A prospective cost-effectiveness study of trigeminal neuralgia surgery. Clin. J. Pain 21(4), 317-322 (2005). 
111 Flickinger JC, Pollock BE, Kondziolka D et al. Does increased nerve length within the treatment volume improve trigeminal neuralgia radiosurgery? A prospective double-blind, randomized study. Int. J. Radiat. Oncol. Biol. Phys. 51(2), 449-454 (2001).

112 Kishore-Kumar R, Max MB, Schafer SC et al. Desipramine relieves postherpetic neuralgia. Clin. Pharmacol. Ther. 47(3), 305-312 (1990).

113 Watson CP, Evans RJ, Reed K, Merskey H, Goldsmith L, Warsh J. Amitriptyline versus placebo in postherpetic neuralgia. Neurology 32(6), 671-673 (1982).

114 Graff-Radford SB, Shaw LR, Naliboff BN. Amitriptyline and fluphenazine in the treatment of postherpetic neuralgia. Clin. J. Pain 16(3), 188-192 (2000).

115 Goldstein DJ, Lu Y, Detke MJ, Lee TC, Ivengar S. Duloxetine vs. placebo in patients with painful diabetic neuropathy. Pain 116(1-2), 109-118 (2005).

116 Raskin J, Pritchett YL, Wang F et al. A double-blind, randomized multicenter trial comparing duloxetine with placebo in the management of diabetic peripheral neuropathic pain. Pain Med. 6(5), 346-356 (2005).

117 Forssell H, Tasmuth T, Tenovuo O, Hampf G, Kalso E. Venlafaxine in the treatment of atypical facial pain: a randomized controlled trial. J. Orofac. Pain 18(2), 131-137 (2004).
118 Moore RA, Wiffen PJ, Derry S, McQuay HJ. Gabapentin for chronic neuropathic pain and fibromyalgia in adults. Cochrane Database Syst. Rev. 3, CD007938 (2011).

119 Frampton JE, Foster RH. Pregabalin: in the treatment of postherpetic neuralgia. Drugs 65(1), 111-118 (2005).

120 Norrbrink C, Lundeberg T. Tramadol in neuropathic pain after spinal cord injury: a randomized, double-blind, placebo-controlled trial. Clin. J. Pain 25(3), 177-184 (2009).

121 Femiano F, Gombos F, Scully C, Busciolano M, De Luca P. Burning mouth syndrome (BMS): controlled open trial of the efficacy of $\alpha$-lipoic acid (thioctic acid) on symptomatology. Oral Dis. 6(5), 274-277 (2000).

122 Femiano F. Burning mouth syndrome (BMS): an open trial of comparative efficacy of $\alpha$-lipoic acid (thioctic acid) with other therapies. Minerva Stomatol. 51(9), 405-409 (2002).

123 Femiano F, Scully C. Burning mouth syndrome (BMS): double blind controlled study of $\alpha$ lipoic acid (thoictic acid) therapy. J. Oral Pathol. Med. 31(5), 267-269 (2002).

124 Femiano F, Gombos F, Scully C. Burning mouth syndrome: open trial of psychotherapy alone, medication with $\alpha$-lipoic acid (thioctic acid), and combination therapy. Med. Oral 9(1), 8-13 (2004).
125 Gremeau-Richard C, Woda A, Navez ML et al. Topical clonazepam in stomatodynia: a randomized placebo-controlled study. Pain 108(1-2), 51-57 (2004).

126 Petruzzi M, Lauritano D, De Beneditis M, Baldoni M, Serpico R. Systemic capsaicin for burning mouth syndrome: short-term results of a pilot study. J. Oral Pathol. Med. 33(2), 111-114 (2004).

127 Maina G, Vitalucci A, Gandolfo S, Bogetto F. Comparative efficacy of SSRIs and amisulpride in burning mouth syndrome: a single-blind study. J. Clin. Psychiatry 63(1), 38-43 (2002).

128 White TL, Kent PF, Kurtz DB, Emko P. Effectiveness of gabapentin for treatment of burning mouth syndrome. Arch. Otolaryngol. Head Neck Surg. 130(6), 786-788 (2004).

129 Heckmann SM, Heckmann JG, Ungethum A, Hujoel P, Hummel T. Gabapentin has little or no effect in the treatment of burning mouth syndrome - results of an open-label pilot study. Eur. J. Neurol. 13(7), e6-e7 (2006).

130 Lopez V, Alonso V, Marti N, Calduch L, Jorda E. Marked response of burning mouth syndrome to pregabalin treatment. Clin. Exp. Dermatol. 34(7), e449-e450 (2009). 